\title{
Bell's palsy in association with a cerebellar arachnoid cyst
}

\author{
Mohammad Hasham Ahmad, ${ }^{1}$ Tayyib Hayat $^{2}$
}

${ }^{1} S c h o o l$ of Medicine and Dentistry, University of Aberdeen, Aberdeen, UK ${ }^{2}$ Newham University Hospital, London, UK

\section{Correspondence to}

Mohammad Hasham Ahmad, hashamahmad@doctors.org.uk

Accepted 25 March 2015
CrossMark

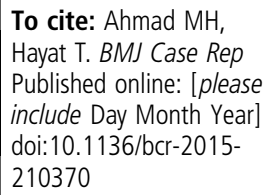

\section{DESCRIPTION}

A 47-year-old woman presented with an episode of left-sided Bell's palsy. The patient was treated with corticosteroids with complete recovery in 3 months. However, coincidental with the onset of the Bell's episode, she began experiencing headaches in the occipital region. Clinical examination revealed only lymphadenopathy in the left posterior cervical chain. Secondary causes of Bell's palsy were investigated with MRI of the brain, which demonstrated a large well-circumscribed mass in the posterior fossa (figure 1). MRI showed marked hyperintensity on axial T2-weighted images (T2WIs; figure 1A-C) and hypointensity on sagittal T1WI (figure 1D) and coronal T1WI (figure 1E, F). A radiological diagnosis of an arachnoid cyst was made.

Arachnoid cysts are benign cerebrospinal fluidfilled divisions of the arachnoid layer. They are predominantly primary in nature, but may also be secondary due to the existence of prior pathological causes such as infection and head injury. ${ }^{1}$ Arachnoid cysts are known to develop de novo, and increase or decrease in size. ${ }^{2}$ Growth or development of the cyst can cause headaches and other neurological symptoms, and may require neurosurgical treatment. ${ }^{2}$ The association of occipital headaches in this case is a known symptom of arachnoid cyst irritability, and cranial nerve $(\mathrm{CN})$ palsies have previously been identified as an uncommon sequela. ${ }^{3}$ Growth of the lesion may have resulted in an increase in the posterior fossa pressure with associated mass effect, visible as compression of the facial nerve (CN VII). In this case, after resolution of the Bell's palsy, discussions with the neurosurgical team advised that surgical intervention for the cyst was unnecessary.

\section{Learning points}

- MRI is an effective modality for imaging and diagnosis of arachnoid cysts.

- Arachnoid cysts can increase or decrease in size resulting in neurological symptoms.

- Persistence of symptoms may require neurosurgical intervention for management of such cases.
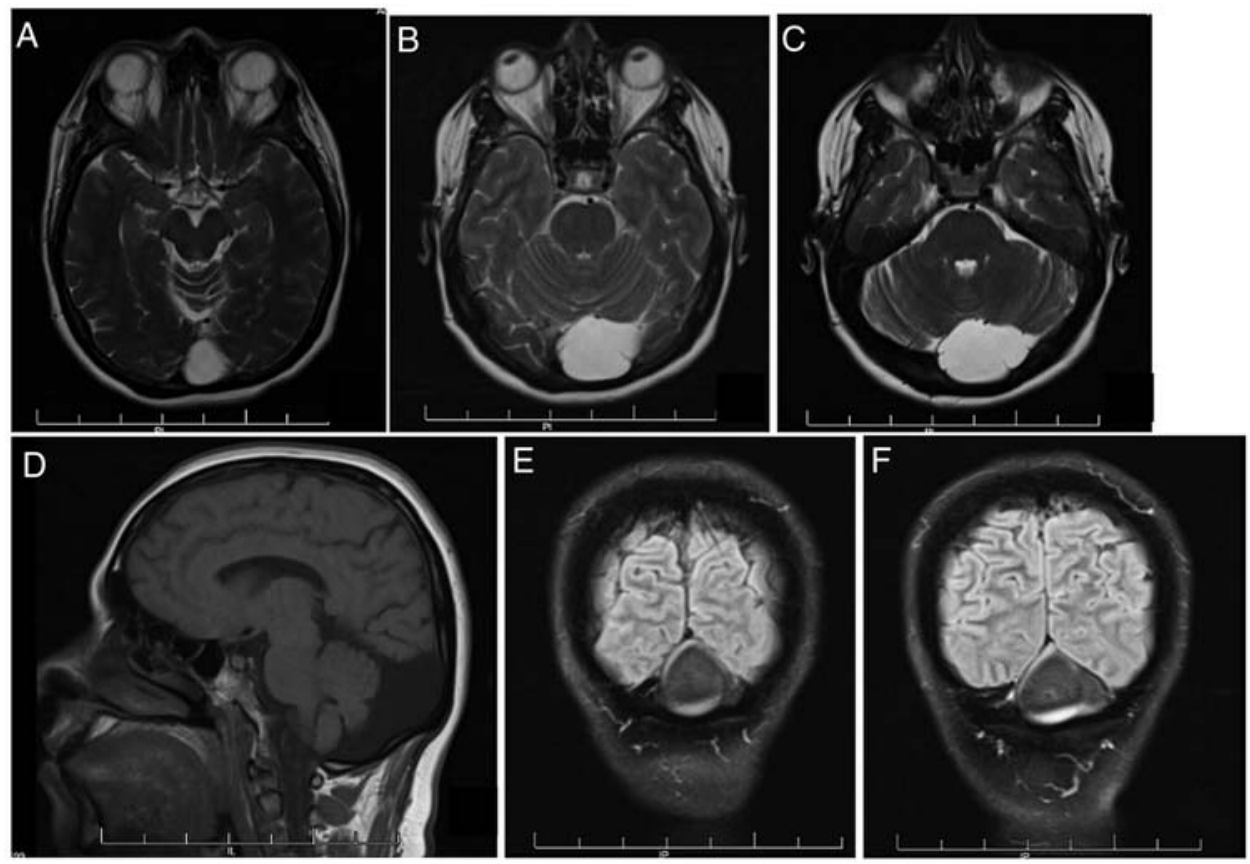

Figure 1 Axial T2-weighted (A-C), saggital T1-weighted (D) and coronal T1-weighted (E and F) images showing a large well-circumscribed arachnoid cyst in the posterior fossa. 
Contributors MHA was involved in gaining history and consent from patient. TH was responsible for approval of the manuscript.

Competing interests None declared.

Patient consent Obtained.

Provenance and peer review Not commissioned; externally peer reviewed.

\section{REFERENCES}

1 Ross L, Drazin D, Eboli P, et al. Atypical tumors of the facial nerve: case series and review of the literature. Neurosurg Focus 2013;34:E2.

2 Westermaier T, Schweitzer T, Ernestus RI. Arachnoid cysts. Adv Exp Med Biol 2012;724:37-50.

3 Al-Holou WN, Terman S, Kilburg C, et al. Prevalence and natural history of arachnoid cysts in adults. J Neurosurg 2013;118:222-31.

Copyright 2015 BMJ Publishing Group. All rights reserved. For permission to reuse any of this content visit http://group.bmj.com/group/rights-licensing/permissions.

BMJ Case Report Fellows may re-use this article for personal use and teaching without any further permission.

Become a Fellow of BMJ Case Reports today and you can:

- Submit as many cases as you like

- Enjoy fast sympathetic peer review and rapid publication of accepted articles

- Access all the published articles

- Re-use any of the published material for personal use and teaching without further permission

For information on Institutional Fellowships contact consortiasales@bmjgroup.com

Visit casereports.bmj.com for more articles like this and to become a Fellow 